\title{
Pakistan NFC Award 2009 and People's Perceptions: A Case Study of Balochistan
}

\author{
Musarrat Karamat Ali \\ Dr. Amanat Ali Jalbani
}

\begin{abstract}
Revenue distribution is an obligation of Federal Government under proviso of 1973 Constitution of Islamic Republic of Pakistan on annual basis. National Finance Commission should be constituted after five years to award the formula in accordance with the demand and consensus between the Federal State and Provinces. During the last 18 years, the formula has not been revised and Pakistan was distributing its revenue on the single criteria of population. Under these circumstances serious prejudice caused to the people of Balochistan and this has led them to be deprived of their due share of revenue on the basis of area, backwardness and poverty. This study is an attempt to identify the root causes of unrest in Balochistan and to analyze the situation after the announcement of 7th NFC Award.
\end{abstract}

Keywords: Revenue sharing, NFC National Finance Commission (NFC) Award, unrest.

\section{Introduction}

\subsection{Background of the Study}

NFC (National Finance Commission) is constituted under the Constitution of Pakistan1973 for the Distribution of Revenues between the Federation and the Provinces (Constitution of Islamic Republic of Pakistan, 1973) on annual basis. Taxes are collected from each province and then they are pooled and redistributed by the Federal Government through a designed formula by the National Finance Commission which is known as NFC Award. Since 1973, after the consensus on the Constitution, there have been three national finance commission awards enforced in 1974, 1991 and in 1997. But the three formulas in 1979, 1984 and in 2000 could not be implemented or even agreed upon since they failed to reach consensus at the national level. The taxes which were included in the pool are (1) Income taxes (2) General sales tax (3) Wealth taxes (4) Capital gains taxes and (5) Custom duties. All the taxes were collected as the major source of revenue for the government and then the redistribution of this revenue was always a debatable issue. The seventh meeting of 7th NFC award was held in the port city of Gwadar on 30th December 2009 and the four provincial ministers signed the consensus document under the elected government led by Syed Yousuf Raza Gillani. In this award, it was decided that provincial share of the divisible pool would increase from the present 47.5 per cent to 56 per cent in the first year of NFC (2010-2011) and 57.5 per cent in the remaining

\footnotetext{
Musarrat Karamat Ali is a Lecturer at Balochistan University of Information Technology, Engineering \& Management Sciences (BUITEMS) Quetta, musarrat.ali@buitems.edu.pk

Dr. Amanat Ali Jalbani is Vice President Academics of SZABIST, Karachi, jalbani@szabist.edu.pk
} 
years of the award under the vertical distribution of resources. (Minutes of the 6th meeting of NFC held in Lahore, 9-10 December 2009) The federal government has agreed to cut tax collection charges from 5 per cent to 1 per cent and this amount would also be added to the divisible pool. About the most controversial issue of sales tax on services, the national finance commission recognized sales tax on services as a provincial subject. The formula which is decided for the distribution of sources constituted the following indicators: Multiple Indicators Weights

1) Population $82 \%$

2) Poverty/Backwardness $10.3 \%$

3) Revenue Collection/Generation 5\%

4) Inverse Population Density $2.7 \%$ (Urban-Rural)

Musarrat Karamat Ali is a Lecturer at Balochistan University of Information Technology, Engineering and Management Sciences (BUITEMS), Quetta, musarrat.ali@buitms.edu.pk Dr. Amanat Ali Jalbani is the Vice President Academics and Dean of Management Sciences at SZABIST, Karachi, jalbani@szabist.edu.pk

Out of $56 \%$ provincial share of total divisible pool, financial resources will be distributed among the provinces in following ration: Punjab - 51.74\%, Sindh $-24.55 \%$, KP - $14.62 \%$ Balochistan - 9.09\% (7th meeting of NFC at Lahore, 9-10 December 2009) In Pakistan, Balochistan is the largest Province geographically. It consists of approximately $43 \%$ of the total area of Pakistan.

According to the 1998 census, Balochistan had a population of roughly 6.5 million and the projections taken by the government based on the 1998 Census the population in 2009 was 11,934,339 ( Bureau of Statistics Pakistan, 2010) which makes 5\% of total population of Pakistan. As it was mentioned earlier that the first NFC award took population as the sole criterion for the distribution of revenue among provinces and as Balochistan is least populated, it had the least share of total revenues which was $2 \%$ to $3 \%$ of total revenues. Balochistan has highly scattered population into far-flung areas. The economy mainly depends upon the natural resources. The two districts of Balochistan ?Turbat and Noshki ? are among the lowest in education all over the world (UNESCO report, 2009). This is alarming situation despite having rich mineral resources. Although autocratic regimes of Sikandar Mirza, Ayub Khan, Ziaul Haq and Pervez Musharaf had adverse effects on masses but the elected Prime Minister Zulfiqar Ali Bhutto's government also ordered military operation against Marri and Mengal Tribes in Balochistan.

Balochistan's social set up is predominantly tribal in nature compare to other provinces. The ineffective land reforms and traditional tribal lords control the lives of common people in Balochistan. General perception is that these lords suppress common people and obstruct developmental activities in the region which includes establishment of educational institutions, infrastructure, health facilities, provision of clean water, exploration of new well heads and mineral resources. They receive funds/packages from the federal government which did not have any trickle down effects on masses. The people remained illiterate, unemployed and deprived of basic needs and decent living environment which has resulted in unrest in Balochistan. The democratic regime of 1970s established some 
industries like Bolan Textile Mills, Harnai Woolen Mills and various other industries at Hub industrial zone but almost all of those failed which reflects badly on economic conditions of general masses. Balochistan always demanded its rights from the Federal Governments but it has been kept deprived of its due share in the total revenues through NFC. Natural gas is the main earning source but the royalty which was given has always been minimal and new well heads were not established in the region. The following questions will be used in conducting this study:

1. What are the main characteristics of NFC award 2009 and why it is different from the previous awards?

2. What were the recommendations of Balochistan Finance department and financial experts to the national finance commission for this award?

3. What are the pre and post opinions of politicians, public and experts on this award?

4. What will be the overall impact of this award on the recent political unrest and law and order situation in Balochistan?

\section{Following are the objectives of this study:}

- $\quad$ To analyze the National Finance Commission Award 2009 thoroughly and evaluate its importance on the recent critical situation when there is political unrest in Balochistan and Law and order situation is worsening due to their share in the total revenues.

- To discover the opinion of experts, politicians and economists in Baluchistan?

- To determine whether NFC has contributed to or is the cause of unrest in Balochistan.

\subsection{Problem Statement}

Unjust revenue sharing is always the root cause of socio-economic and political conflicts in Pakistan. In the past, different governments in Pakistan have used population as the single criterion which has created a sense of deprivation in the people of Balochistan. Since this is the 7th NFC Award and announced after 18 years, it has adopted multiple indicators for revenue distribution. This study has been conducted to investigate the major causes of unrest in Balochistan according to people's perception and their opinion after announcement of this award.

\section{Literature Review \& Theoretical Framework}

\subsection{Revenue Sharing in Global Perspective}

Different forms of revenue sharing have been used in several countries, including Canada, India, and Switzerland. From 1972 to 1986, the U.S. pursued a revenue sharing 
program in which state and local governments received federal funds to spend as they saw fit (Encyclopedia Britannica). In Nigeria, an horizontal sharing formula is to be employed on the basis of equality of states (45.23 per cent); population ( 25.60 per cent); population density (1.45 per cent); internal revenue generation effort (8.31 per cent); landmass (5.35 per cent); terrain (5.35 per cent); rural roads and inland waterways (1.21 per cent); potable water (1.5 per cent); education (3 per cent) and health (3 per cent) (Government of Nigeria). In India, the Constitution of India provides the establishment of a Finance Commission for the purpose of allocation of certain resources of revenue between the Union and the State Governments. The Finance Commission is established under Article 280 of the Constitution of India by the President. (Government of India, 2010).The qualifications, powers and procedures of the Commission itself are regulated by the Finance Commission (Miscellaneous Provisions) Act 1951. Under Article 280 of the Constitution the Finance Commission is required to make recommendations to President. In India, the thirteenth 2007 Vijay Kelkar 2010-2015 Finance commission awards have come in February 2010. FC-XII assigned a weight of 25 per cent to population, 50 per cent to per capita income distance, 10 per cent to area and 7.5 per cent each to tax effort and fiscal discipline in the formula for arriving at the share of each state in tax devolution. (Report of the Thirteenth Finance Commission of India).

\subsection{Revenue Sharing in Pakistan}

Pakistan is a federation and the basic framework for allocation of the fiscal power and distribution of revenues between the Federation and the Provinces is given in the Constitution (Government of Pakistan, 1997). There is a divisible pool comprising the net proceeds of specified taxes collected by the Federal Government which is shared by all the units in the Federation (Report of the National Finance Commission, 1996). National finance commission Award is the distribution formula of revenues between the federation and the provinces of Pakistan. Pakistan is the federation of four provinces ? Punjab, Sindh, Khyber Pakhtunkhwa and Balochistan. The intergovernmental fiscal transfer is a prominent feature of the public financial structure of Pakistan. These transfers either take the form of revenue sharing, straight grants and loans. In Pakistan, financial resource transfers take place at four stages: from the federal government to the provincial Government; second, from the provincial government to the local governments; third, from federal to local; and fourth from local to local governments. (Jaffery and Sadaqat, 2006). The different types of flow of funds are:

Revenue sharing transfers: which include taxes collected by the federal government and shared with the lower level of government.

Recurring grants: in which the higher level of government subsidize a particular activity (e.g. primary education). Development Grants/Loans: in this the higher level of government make specific or block development grants to lower government.

Some of the development is also financed through loans. Loans; transfers from federal to provincial governments in the form of loans (Jaffery and Sadaqat 2006)

Resource sharing can be divided into four eras; 1) Pre-independence era (before 1947) 
2) Post independence era (1947-54) 3) during one unit period (1955-1970) and 4) NFC awards following the 1973 constitution of Pakistan (Iftikhar Ahmed et al, 2007). Before independence there was British Rule and they were following the 1935 Act of India. GOVERNMENT OF INDIA (DISTRIBUTION OF REVENUES) (AMENDMENT) ORDER 1940 came with the solution of the questions related to revenue distribution between the Central Government and the Provinces. Sir Otto Niemeyer came to India and gave the answers to the questions raised in Section 138 of The Indian Act 1935. The percentage which he suggested for the divisible pool for the provinces was $50 \%$. After Independence, Pakistan adopted the same formula for revenue sharing with some adjustments in railway budget, sharing of Income and sales taxes (Pakistan 1991). After the independence, Sir Jeremy Raisman was assigned to formulate a feasible revenue sharing formula between Federation and the Federating Units of the Country. The Raisman Award was presented in December 1947(Pakistan 1991, Iftikhar Ahmed et al., 2007) and was adopted on April 1, 1952. In 1955, Pakistan was divided into two units; East Pakistan and West Pakistan. Punjab, N.W.F.P and Sindh were declared One Unit and were called West Pakistan, before this they were considered separate Provinces and they have their separate share in the revenues. After this revenue were shared only between these units. In 1961 and in 1964 two awards came for revenue sharing under this

arrangement. East Pakistan and West Pakistan got 54 and 46 percent share respectively in the divisible pool. 30 per cent of sales tax was specified to the provinces on the basis of collection in their respective areas (Pakistan, 1991 and Iftikhar Ahmed et al., 2007) and the duties on agricultural land and capital value tax on immoveable property were given to the units as per their collection. In 1964, the share of revenue remained the same between the two unites. The share of revenue between centre and the provinces was 35:65 per cent. In 1970, the West Pakistan was divided into four provinces again and the share of provinces was Punjab 56.5\%, Sindh $23.5 \%$, N.W.F.P $15.5 \%$ and Balochistan 4.5\%. (Pakistan 1991, Ifkikhar Ahmed et al., 2007). A committee was also set up to recommend the revenue sharing between the federal government and the provinces. The share between the Centre and the Provinces is 20:80 per cent and the share of the provinces remained the same.

\section{2.1 National Finance Commission Awards}

In Pakistan, National Finance Commission was constituted in 1973 and the only criterion taken for revenue distribution was population. The first formula of the NFC award came in 1974 by the then elected Government of Pakistan which was led by Zulfiqar Ali Bhutto and the National Finance Commission constituted Federal Finance Minister (Chairman), Provincial Finance Ministers and other concerning experts which the President may appoint after consultation with provincial Governors (Constitution of Pakistan, 1973). In this award, the only criterion taken for revenue distribution among the Provinces is population which was quite controversial. Custom duties were kept out of divisible pool and sales tax was federalized completely. The second NFC award came in 1979 in the President General Zia ul Haq marshal law regime. The President constituted the 2nd NFC under the Chairmanship of Mr.Ghulam Ishaq Khan, Federal Finance Minister in 1979. It held no meetings and resultantly made no proposals. The 3rd NFC Award was 
also composed during President Zia's Government in 1985 under the chairmanship of then Federal Finance Minister Dr. Mehboob ul Haq. They held nine meetings but reached no consensus. The 4th NFC award came in 1991 by elected government headed by Mian Muhammad Nawaz Sharif. This NFC award recognized the rights of the provinces on natural resources and the provinces were given royalty and gas development surcharge on oil and gas. And the 5th NFC award was declared in February 1997 by a caretaker government of Farooq Ahmed Leghari and Prime Minister late Malik Meraj Khalid. Mr.Shahid Javed Burki, Finance Minister was its Chairman. It turned out to be the most controversial NFC award, though still operative, despite the expiry of its fiveyear term in 2002.

The 6th NFC Award was composed during General Pervez Musharaf's regime. The chairman was Mr.Shukat Aziz (Federal Finance Minister). It also held 11 meetings but reached no consensus. The meetings were held for 6th NFC award in 2002 and Dr. Ashfaque Hassan Khan was assigned to have detailed study on the issue keeping in view the following questions like what other indicators can be included? What would be the measurement, methodology for such indicators? (Government of Pakistan, 2002 working paper unpublished). He analyzed revenue sharing formula of 17 countries including Argentina, Brazil, Colombia, India, Indonesia, Malaysia, Japan, Mexico, Nigeria, Philippines, USA, Canada, Australia, Germany, UK, Korea and Pakistan. He found out in 2002 that all the countries are using different indicators for revenue sharing except Pakistan which was using only population. The weights were assigned to different indicators such as population, density, income distance method, area, index of infrastructure, tax efforts, fiscal discipline, tax collection, social development, land area, equal share etc. The weightage to different indicators is different in these countries.

\subsubsection{Recommendations of Balochistan for NFC 2009}

7th National Finance Commission was established in 2009 under the supervision of Federal Finance Minister Mr. Shaukat Tareen, the members from Balochistan were Mr. Muhammad Asim Kurd ( Finance Minister Balochistan), Dr. Gulfraz Ahmed( member), Mr. Mahfooz Ali Khan (Finance Secretary Balochistan) and Mr. Noor-ul-Amin Mengal ( Additional Secretary Budget).

It was discussed earlier that Natural Gas was the major source of revenue generation for Balochistan. On gas the province is liable to receive:

1) GDS (Gas Developmental Surcharge)

2) Royalty 3) Excise Duty on gas (Straight Transfer to Provinces under article 161 of the Constitution after deduction of $5 \%$ collection charges).

Member of Balochistan suggested that the NFC should continue to meet after every three months even after the announcement of the award in order to review the implementation of the award and he also emphasized to review and revise the formula. Balochistan produces $21 \%$ of total gas and consumed only $7 \%$. The sale price and the wellhead price was determined by the Federal Government and if the wellhead price 
of a province was historically low, the royalty and excise duty would also be at the lowest side. With this arrangement in place, Balochis perceived that although Balochistan was generating 90 billion as GDS but most of it was invested in other provinces for exploration of gas and thus Balochistan was deprived of its due share, hence they recommended that the Federal Government should pay arrears to Balochistan.

Another suggestion from Balochistan was that the National Finance Commission should include multiple indicators for revenue sharing and should include area as one of the indicator (Government of Pakistan, Document unpublished). During the fourth meeting of 7th NFC Award, the Governor State Bank of Pakistan was invited to brief the participants of National Finance Commission about the monetary policy and loans extended by the commercial banks and DFl's. Dr. Gulfraz pointed out that the investment through lending by commercial banks in Balochistan was the lowest among all the provinces and he recommended that the bank should take the corrective measures to increase the investment in Balochistan. For the horizontal distribution, technical member from Balochistan suggested multiple indicators population $75 \%$, Inverse population density $10 \%$, revenue generation $5 \%$ and $\mathrm{HDI}$ (poverty) 10\% (HDI: The Human Development Index combines three basic aspects of human development: health, knowledge, and standard of living. Data on each country's progress in each area is collected and released annually by UNDP. Pakistan HDI is 0.551 (UNDP report)) and for vertical distribution, it was suggested that the federal government should increase the share of the provinces from $47.5 \%$ to more than $50 \%$. The 7 th NFC award came on 30th December 2009 after 18 years and first time multiple indicators are taken for revenue distribution between the Federal and the Provincial Governments.

\section{Theoretical Framework}

Different countries are using different Revenue sharing Formulas within the state and Federal Government. By using the above information of countries, I developed three models of revenue sharing. Once it was decided that Pakistan would adopt multiple indicators for revenue sharing; the next issue was the choice of factors or indicators that could be included in the formula and their reliability of estimates. Pakistan adopted four factors or indicators for revenue sharing. In the absence of reliable estimates with regard to development gap, state of infrastructure; it was not desirable to include an indicator in the revenue sharing which is difficult to measure. The indicators should be easy to measure with standard methodology and should be free from controversy and value judgments. The rationale for using the above indicators is as under 

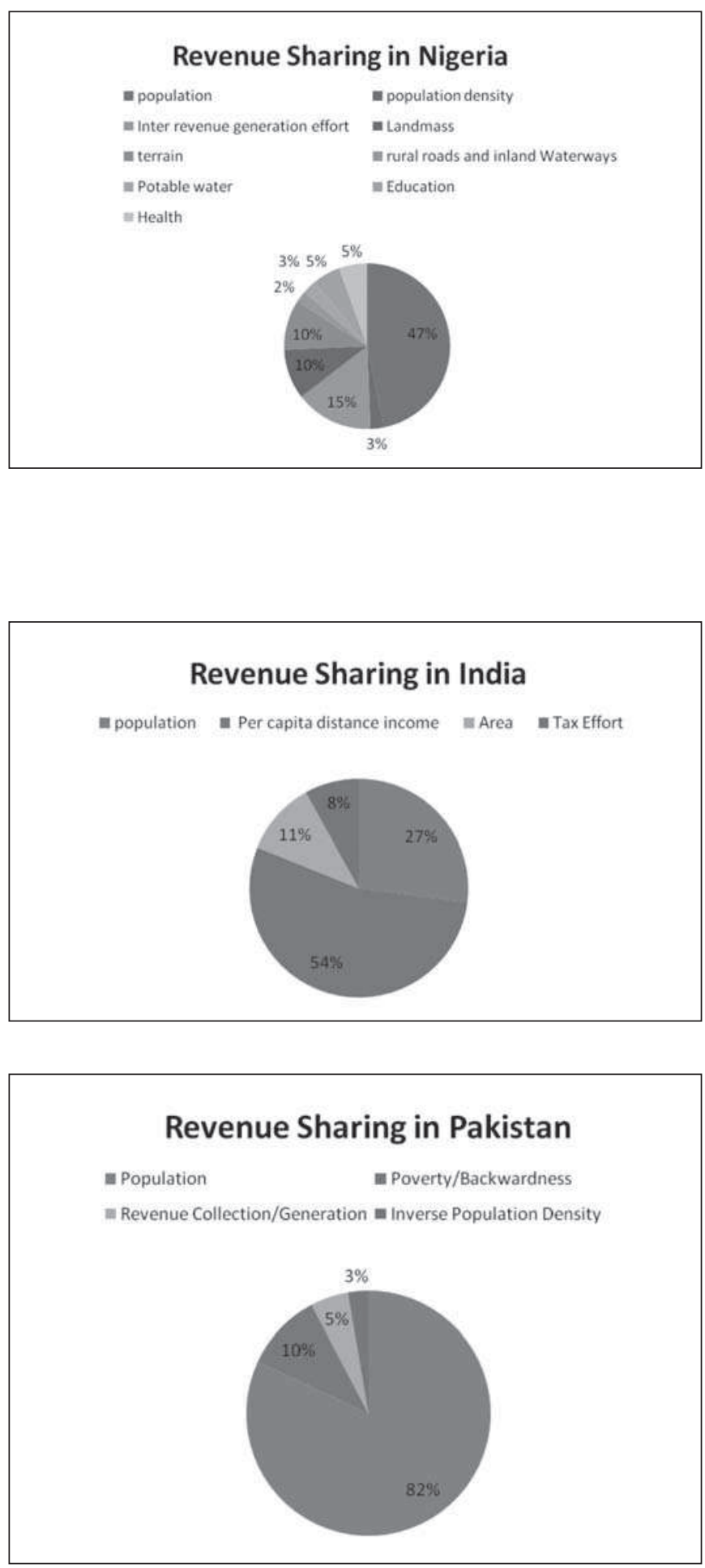


\subsection{Population}

Population was the sole criterion for revenue distribution in the past between the federation and the federating units and it can be defined as the Statistical collection of human beings in an area. It is also key indicator of revenue sharing in many countries like India and Nigeria. The data regarding population are readily available in the countries through Census. In Pakistan, the last Census was done in 1998 and after that the projections or estimates have been taken for population measurement in Pakistan. The data collected in 1998 and the yearly estimates for population will be used for this criteria and it is the largest criterion as $82 \%$ revenue will be distributed on this criterion for the next five years in Pakistan.

\subsection{Inverse Population Density/Area}

In most of the countries, area is used as an indicator as it is easy to measure area of any country and data with regard to each province is known to all of us. Dr. Ashfaq was also of the view that in absence of reliable estimates regarding developmental gap, state of infrastructure and social development, area can be used as a proxy for these indicators (2nd meeting of 6th NFC Award on 30th June 2002, Government of Pakistan Unpublished). The underlying assumption is that the large areas require more resources to reduce developmental gap or relative backwardness. Inverse population density means movement/migration of people from one area to another due to a number of factors such as harsh climate or the environmental conditions in that particular area. Due to harsh climatic conditions and in absence of any facilities, people from mountainous regions have to leave their areas and travel to warm places/less mountainous areas, where they can find shelter and food easily. This phenomenon is prominent in Balochistan and NWFP, where people have to move because of snowfall and absence of any food for their cattle/goats/sheep and for their own selves. These migrations are the sign of backwardness of that area. Balochistan and Khyber Pakhtunkhwa presented a proposal to include inverse population density in the NFC formula for distribution of funds so that they can get extra funds from Federal Government for utilization in uplifting the infrastructure of these mountainous areas, so that living conditions of people can be improved. By getting fund under this criterion, the provincial governments are determined to develop those areas so the people can live in the conducive environment and would not migrate. This factor has been given $3 \%$ in revenue sharing.

\subsection{Revenue Collection and Generation}

If a province contributes more in divisible pool, it should be properly rewarded for its contribution. In NFC Award meetings, Sindh proposed to include this indicator in revenue sharing formula. With regard to measurement of revenue collection, it is important to first consider two factors i.e. the goods can be imported for various destination in the country but generally cleared at the Karachi Port. Customs duty collected from the imported items can not be treated as revenue from Sindh alone. The origin of sales tax is difficult to determine because goods can be produced at one place and can be consumed at many places. Hence in this regard, Dr. Ashfaq has maintained that income tax and central excise duty may be taken as indicator for revenue collection. 


\subsection{Poverty and Backwardness}

Poverty refers to the condition of not having the means to afford the basic human needs such as clean water, nutrition, healthcare, education, clothing and shelter (Encarta Poverty definition). Backwardness is lack of normal development of intellectual capacities. An economically backward economy is defined as one which makes less progress than normal. Ex-president of USSR, Gorbachev once said, 'If you don't move forward, sooner or later you begin to move backward.' Pakistan is an underdeveloped country so all the members of the NFC committee are in favor to include poverty as an indicator in the revenue sharing formula.

\section{Research Methodology}

This exploratory case study introduces multiple indicators used for revenue sharing in NFC 2009. The research will use a contextual analysis of this award by taking the opinions of the people of Balochistan. Instead of a hypothesis in research to validate relationship between NFC awards and Unrest in Balochistan, an appropriate theoretical framework has been established through literature review. Non-probability sampling is used due to the non-availability of the known population. A sample of four classes has been selected by using the judgmental and convenience sampling. A sample of approximately 100 has been taken at first that comprises Educated General Public (Lawyers and Academicians) 30\%, Experts (Economists and Government Officials) $35 \%$ and Politicians $35 \%$. Cross-Sectional study has been carried out as the primary data are collected at a single point in time by distributing the questionnaire and personal interviews. The questionnaire developed had 14 questions and I used two scales while developing the questionnaire, i.e. Dichotomous Scale and Ratio Scale. Multiple choice questions and open ended questions are also included for taking suggestion. The level of researcher interference was at minimum as the researcher did not put any leading questions to the respondents and gave full liberty to the respondents to give their remarks and suggestions.

\section{Data Analysis and Interpretations}

\subsection{Demographic Profiles}

Most of the respondents were young, in the age group of 15-30. The respondents were educationist, Government servant, lawyers and Economists. $45 \%$ of the respondents had master's degree and they had the knowledge of current situation in the country. Media also play a vital role in creating awareness among the masses. As it was the first time that this type of research has been conducted in Balochistan, so it was quite surprising for the researcher that many respondents had two to three degrees in different study programs which could be due to increasing rate of unemployment in this region. 

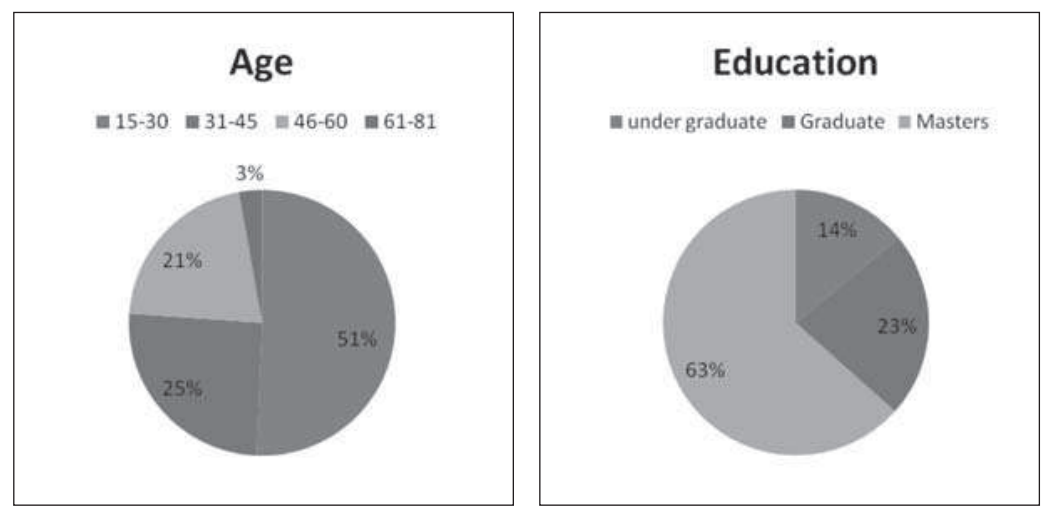

The region is suffering low literacy rate as compared to other provinces of Pakistan and also has no industries which can provide job opportunities to these people. Most of them prefer to do government jobs as it provides them flexibility in timing and job security. As the topic was about the revenue sharing and I did the Convenience sampling taking three classes in my sample so these figures can not be taken as the whole picture of education in this province. Balochistan has only five universities and three of them are situated in the capital city of Quetta. Most of the politicians are also settled in Quetta due to presence of Provincial Assembly. The researcher tried to take response from people who belong to different regions and tribes in Balochistan as many of the respondents came to Quetta for education and for jobs.

\subsection{Do you think that there is unrest in Balochistan?}

$90 \%$ of the respondents agreed with the notion that there is unrest in Balochistan and it prevails in one form or another due to typical social setup which is in total contrast to the other parts of the country. The periodical long spans of dictatorships, semi democratic and incompetent leaderships totally failed to address grave complicity of current law and order situation in Balochistan and could not exploit the geographic and strategic location and mineral rich lands of this vast province since very beginning.

\section{Unrest in Balochistan}

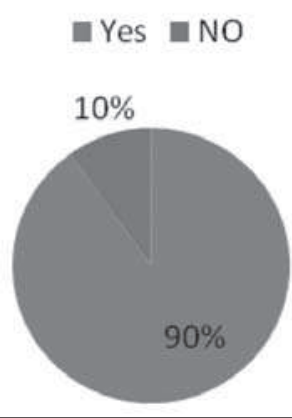


The Balochistan, a typically tribal society with feudal psych of ruling classes remained in rivalry with military and democratic forces of center due to later force undue use of force, unjust distribution of revenues, corruption, almost, no representation in public and political forums of local Baloch. On the other hand, nothing had been done to meet demands of local Baloch leadership and if some funds were released they were insufficient to solve problems of common Baloch populace which is highly scattered in vast lands of this province. The corrupt Bureaucracy generally belongs to other linguist groups. The arrest of Khan Kalat during 1948 Murder of Nawab Nawroz Khan, Judicial killing of Sardar Attaullah Khan Mengal's son during regimes of General Ayub Khan and Zulfiqar Ali Bhutto military operation, exile of Nawab Khair Bushk Marri as well as that of Khan Samad Khan and recent killing of Nawab Akbar Khan Bugti during Pervaiz Musharaf's reign added oil to the burning fire.

\subsection{Have you heard of Pakistan NFC Award 2009 and do you think that the NFC 1973 formula issatisfactory?}

Most respondents heard about the NFC Award through media and as the sample is from economist, educationist, lawyers and politicians, they are well aware of this formula. $55 \%$ of respondents were not satisfied with the NFC Award 1973 as they claimed that due to that formula which was only based on population they were kept backward and they were kept deprived of their due revenue share. According to the literature, in 1970
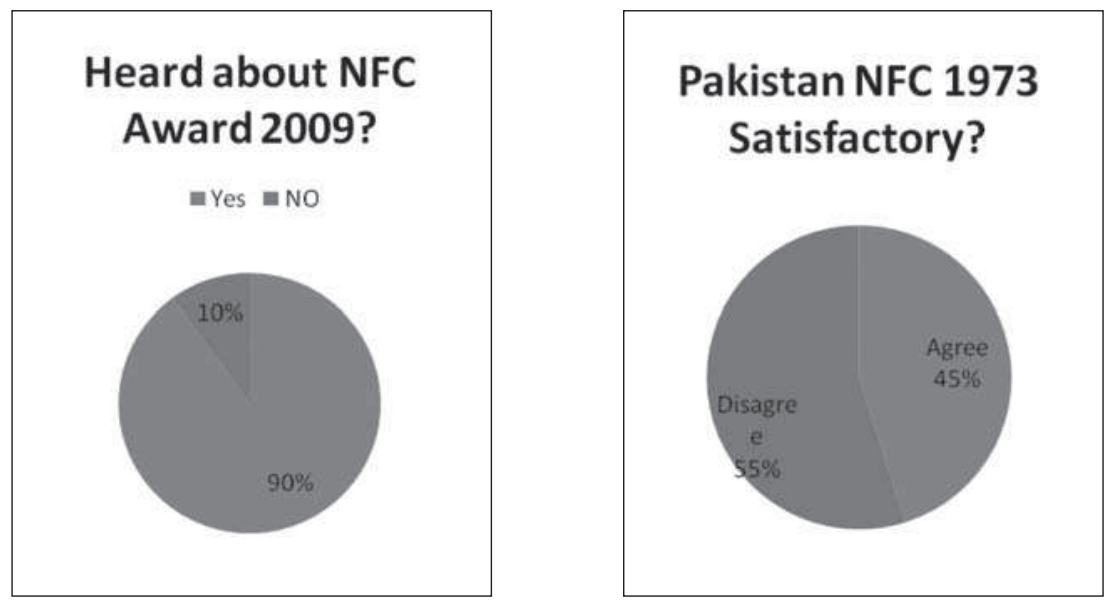

Balochistan was producing $70 \%$ of the total natural gas produced in Pakistan. Now its share has been reduced to $30 \%$ due to non development of new well heads and explorations in this region which the people thought was due to unjust formula of NFC Award 1973.

\subsection{Is NFC award 2009 vital to strengthen ties between Federal Government and Provincial Government and would that be beneficial to Balochistan?}

$67 \%$ of the respondents were of the view that this revenue sharing formula will bring 
positive change in the current situation and will strengthen ties between the Federal and the provincial Government. The basis of formula was known by $63 \%$ of the respondents and the people also agree that this award will be beneficial to Balochistan. The revenue share of Balochistan has been increased from $5.07 \%$ to $9.02 \%$ which will bring extra revenue in the Balochistan. The formula also include indicators like poverty and backwardness and inverse population density which will bring extra share as most people living in this province
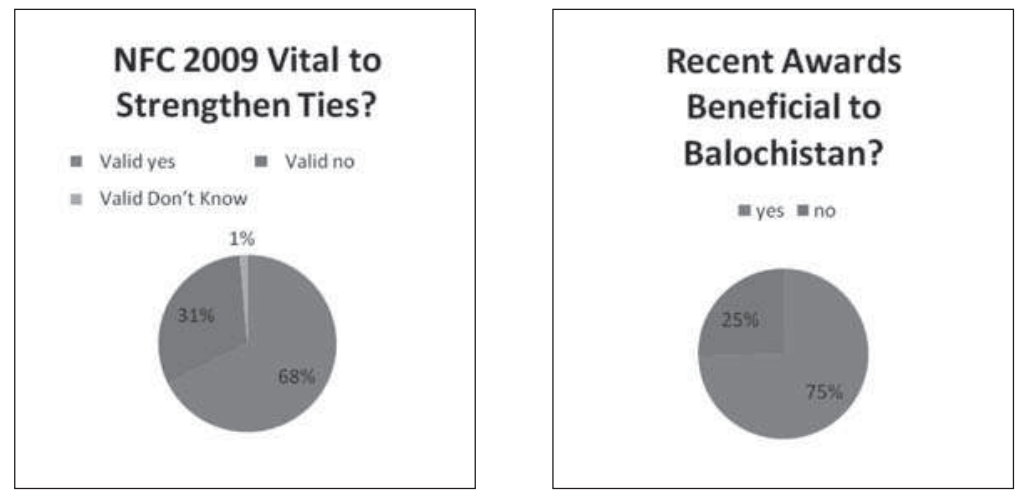

faced severe weather conditions in summer and winter and shift from one area to another favorable area for better facilities of food and shelter. So $74 \%$ of the respondents agreed that this award will be beneficial to Balochistan.

\subsection{If yes, then will there be a trickle down effect of this award?}

According to the Transparency International report published during 2009-10, Pakistan is among the most corrupt nations of the world and a major part of developmental and non-developmental funds are either eaten up or embezzled and rest of the amount used for bribery and kickbacks. $66 \%$ of respondents are of the view that there would be trickledown effect of this formula which is an encouraging sign and shows that indigenous population have faith in their native leaders which is another encouraging sign. It is too early to say whether the hope becomes a reality by implementation of check and balance system and proper use of additional award money for the benefit of public at grass roots level.

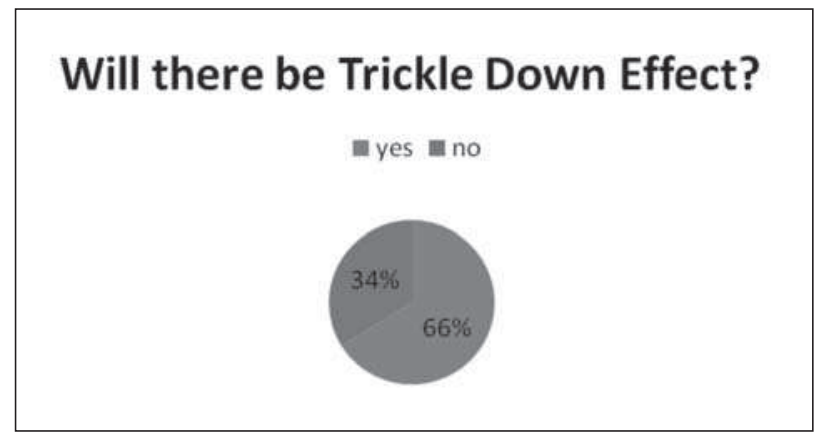




\section{Conclusion and Recommendations}

- The National Finance Commission was established in 1973 and the single criterion was population for revenue distribution amongst Federal and Provincial Governments. Baluchistan's Population remained un-assessed while the last census held during 1998, the Pashtoon Belt refused to take part in the census and there was also no steps taken to calculate the population again. Balochistan's population was considered $5 \%$ of total population of Pakistan and they received the least share in revenue which was based on assumption.

- In Balochistan, the single revenue generating source is natural gas but the province never received any developmental surcharge which hinders the local Governments to discover new wells of gas and oil in the region. Besides controversial projects of Saindak and Rekodiq, copper and gold has been extracted in collaboration with Chinese and Australian government agencies without giving any weight to the opinions of indigenous leadership of Balochistan thus revenue share of Balochistan remained unchanged. The only benefit worth mentioning is of 400 employments mainly of lower grades.

- $\quad$ The main issue which the researcher found out is the widespread presence of mistrust between the local people and Federal Government. Many respondents think that the main cause of unrest in the region is due to military interference and exploitation of local resources without giving due share to the people living in the region.

- The aftermath of Afghan Invasion by the former USSR in 1979 and 9/11 attacks, the energy crisis and economic recession worldwide, Balochistan has emerged as an ideal power route for Central Asian Republics' huge energy resources. Balochistan's precious minerals have attracted the world dominated economic forces in the region and brings total unrest in the province which resulted in target killings of settlers, displacement, missing persons and illegal detentions and extrajudicial killings. India has also exploited the situation as it did in the past during 1971 in Bangladesh and is engaged in cross border terrorism.

- The political unrest, insufficient revenue, untrained human resource, lack of planning and action against the will and desire of local representatives, no infrastructure could be developed to explore natural resources in order to increase revenue generation of Balochistan despite having rich mineral resources, hence the common Baloch remained deprived of their share from NFC award on account of Revenue generation as well.

- $\quad$ Proper plans should be chalked out after assessing the needs of the people of Balochistan with the consent of local leadership and provincial Government without any intervention from the Federal Government.

- $\quad$ Developmental plans should be long-term as well as short-term and they should be monitored and completed in due course of time. 
- $\quad$ Priority should be given to develop infrastructure, means of communication, free education, especially technical and professional in order to explore natural resources and industrialization in the region.

- $\quad$ All the assurances and local leadership concerns should be backed up by legislation for the restoration of their trust in the Federal Government and all steps should be taken to enhance their revenue share for implementation of developmental plans.

- $\quad$ The 7th NFC Award came after the lapse of eighteen years, despite constitutional provisions. It should not happen in future and the NFC Committee should meet after announcement of the award to ensure the implementation of the award.

- $\quad$ Locals also demand Provincial autonomy from the Federal Government which should be granted to avoid the major conflict

- Lastly, peace and security in the region is vital and without them no plan can be implemented in this region. 


\section{References}

Article 160(1) 1973, Constitution of Islamic Republic of Pakistan. Part IV Finance, Property, Contracts and Suits. Chapter 1, Chapter 8 Sharing of Union Tax Revenues 8.26 pg 119 of Report of Thirteenth Finance Commission of India). Fincomindia.com

Encyclopedia Britannica retrieved on 15-03-10, www.britannica.com

Encyclopedia Encarta, 'Poverty' retrieved on 13th April, 2010 from the website http://encarta.msn.com/encnet/features/dictionary/DictionaryResults.aspx?lextype=3 \&search=poverty

Federal Bureau of Statistics, Government of Pakistan. 1998. http://www.statpak.gov.pk /depts/fbs/publications/yearbook2008/Population/16-5.pdf. Retrieved 2010.01.30

Government of Pakistan (1996), Report of National Finance Commission Islamabad. National Finance Commission Secretariat.

Government of Pakistan (2006), The Gazette of Pakistan, "An order further to amend the Distribution of Revenue and Grants-in-Aids Order, 1997". Order No.1 of 2006. Ministry of Law, Justice and Human Rights.

Government of Pakistan, Finance Division (NFC Secretariat) Minutes of the 6th meeting of National Finance Commission at Lahore 9-10 December, 2009 unpublished

Human Development Report, (2010), 'The Real Wealth of Nations: Pathways to Human Development', available at http://hdr.undp.org

Human Development Index (HDI) 2010 Rankings, available at http://hdr.undp.org

Ahmed, Iftikhar Usman Mustafa, Mahmood Khalid (2007) National Finance Commission Awards in Pakistan: A Historical Perspective Pakistan Institute of Development Economics Vol. 33 page no 253-279

Nighat Bilgrami Jaffery and Mahpara Sadaqat 2006), NFC Awards Commentary and Agenda Pakistan Economic and Social Review, Volume 44, No.2 (winter 2006) pp.209-234.

Pakistan Statistical Year Book (2008), Federal Bureau of Statistics - Government of Pakistan. Retrieved 29th January 2010

Revenue Allocation Formula of Nigeria www.nigeriamuse.com

Sabir Muhammad (2001), Dynamic Consequences of the 1997 NFC Award: Provincial Social Sector Expenditure. The Pakistan Developmental Review, Vol. 40(4), part III, pp. 967-984http://www.spdc.org.pk/pubs/nps/nps5.pdf retrieved on 30th January, 2010 
The News 31st December, 2010 www.thenews.com.pk/print3.asp?id=26374, retrieved on 29th January, 2010

Transparency International, Report on Corruption in Pakistan, retrieved from the website http://www.dailytimes.com.pk/default.asp?page $=2009 \% 5 \mathrm{C} 11 \% 5 \mathrm{C} 18 \% 5 \mathrm{Cstory}$

UNESCO Report (2006), 'Pakistan: where are and who are the World's Illiterates?' available at http://unesdoc.unesco.org 